\title{
Deskripsi Kemampuan Berpikir Reflektif dalam Menyelesaikan Soal High Order Thinking Skill (HOTS) ditinjau dari Kecerdasan Logis Matematis Siswa
}

\author{
Hamzah Upu ${ }^{1}$, Rusli ${ }^{1, \text { a) }}$, dan Yulia Pratiwi ${ }^{1, \text { b) }}$ \\ ${ }^{1}$ Jurusan Matematika FMIPA Universitas Negeri Makassar \\ a)rusli.siman@unm.ac.id \\ b)yuliap840@gmail.com
}

\begin{abstract}
Abstrak. Penelitian ini bertujuan untuk mendeskripsikan kemampuan berpikir reflektif dalam menyelesaikan soal High order thinking skill (HOTS) ditinjau dari kecerdasan logis matematis siswa. Jenis penelitian ini adalah penelitian kualitatif dengan menggunakan pendekatan deskriptif. Subjek penelitian ini adalah 3 siswa kelas IX SMP yang masing-masing mewakili satu kategori kemampuan logis matematis. Instrumen yang digunakan dalam penelitian ini adalah tes kecerdasan logis matematis, tes soal HOTS, dan pedoman wawancara. Kemampuan berpikir reflektif siswa mempunyai tiga fase, yaitu: reacting, comparing, dan contemplating. Hasil penelitian ini menunjukkan bahwa: 1) Pada fase reacting; subjek yang kecerdasan logis matematisnya tinggi, sedang, dan rendah memenuhi semua indikator yang harus dilalui dengan bereaksi dengan pemahaman pribadinya. 2) Pada fase comparing; subjek yang kecerdasan logis matematisnya tinggi dan sedang memenuhi semua indikator yang harus dilalui dengan melakukan analisis dan evaluasi terhadap pengetahuannya yang sudah ada; subjek yang kecerdasan logis matematisnya rendah tidak memenuhi indikator apapun. 3) Pada fase contemplating; siswa yang kecerdasan logis matematisnya tinggi memenuhi syarat indikator yang harus dilalui dengan menyelesaikan soal mengacu pada pengetahuan yang diingatnya; subjek yang kecerdasan logis matematisnya sedang dan rendah tidak memenuhi indikator apapun.
\end{abstract}

Kata Kunci: Kemampuan, Berpikir Reflektif, High Order Thinking Skill, Kecerdasan Logis Matematis, SPLDV.

\begin{abstract}
This research was intended to describe student's reflection thinking ability on solving HOTS questions based on students logical mathematical intelligence. This study was descriptive research with qualitative approach. Subjects of this study were ninth grader students of middle school, consisting of one student with high logical mathematical intelligence, one student with moderate logical mathematical intelligence, one student with low logical mathematical intelligence. Instruments in this study were logical mathematical intelligence test, high order thinking skill questions, and interview guideline. For reflective thinking ability, there are three phases that must be through by students. They are reacting, comparing, and contemplating phases. Research result showed that: 1) For reacting phase; students with high, moderate, and low logical mathematical intelligence fulfilled each indicator to react with their personal understanding. 2) For comparing phase; students with high and moderate logical mathematical intelligence fulfilled each indicator by analysing and evaluating their existing knowledge; student with low logical mathematical intelligence doesn't meet any indicators. 3) For Contemplating phase; student with high logical mathematical intelligence fulfilled each indicator by solving the questions referring to the knowledge that she remembered; students with moderate and low logical mathematical intelligence don't meet any indicators.
\end{abstract}

Keywords: Ability, Reflective Thinking, High Order Thinking Skill, Logical Mathematical Intelligence, SPLDV. 


\section{PENDAHULUAN}

Sistem kurikulum yang berlaku di Indonesia adalah kurikulum 2013 yang dirancang dengan penyempurnaan. Model-model penilaian pada kurikulum 2013 mengadaptasi secara bertahap model-model penilaian standar internasional yang diharapkan dapat membantu peserta didik untuk meningkatkan kemampuan berpikir tingkat tinggi (High Order Thinking Skills/HOTS). Hal ini dikarenakan berpikir tingkat tinggi dapat mendorong peserta didik untuk mengetahui secara luas dan mendalam tentang materi pelajaran yang mereka pelajari (Kemendikbud, 2017).

Kemampuan berpikir tingkat tinggi dijelaskan oleh Gunawan (2011) adalah proses berpikir yang mengharuskan siswa untuk memanipulasi informasi yang ada dan ide-ide dengan cara tertentu yang memberikan mereka pengertian dan implikasi baru. Misalnya, ketika siswa menggabungkan fakta dan ide dalam proses mensintesis, melakukan generalisasi, menjelaskan, melakukan hipotesis dan analisis, hingga siswa sampai pada suatu kesimpulan. Kemampuan berpikir tingkat tinggi termasuk kemampuan untuk memecahkan masalah, berpikir kritis, berpikir kreatif, kemampuan berargumen, dan kemampuan mengambil keputusan.

Berpikir kritis, logis, reflektif, metakognitif, dan kreatif merupakan bagian dari berpikir tingkat tinggi. Widodo dan Kadarwati (2013) berpendapat bahwa dengan berpikir tingkat tinggi peserta didik akan dapat membedakan ide atau gagasan secara jelas. Peserta didik juga mampu berargumen dengan baik, memecahkan masalah, mengkonstruksi penjelasan, berhipotesis dan memahami hal-hal kompleks menjadi lebih jelas.

Salah satu kemampuan berpikir tingkat tinggi ialah berpikir reflektif. Fisher (2001) menjelaskan bahwa istilah berpikir reflektif dipopulerkan pertama kali oleh John Dewey. Menurut Dewey berpikir reflektif merupakan cara berpikir efektif, konsisten, dan akurat pada informasi, kepercayaan, atau pengetahuan untuk mendukung hasil yang dituju. Nisak (2013) juga mengemukakan kemampuan berpikir reflektif adalah kemampuan untuk menghubungkan pengetahuan yang telah diperoleh untuk memecahkan masalah baru berkaitan dengan permasalahan lama untuk menarik kesimpulan.

Kemampuan berpikir reflektif sangat diperlukan bagi siswa karena berkaitan dengan pemecahan masalah dalam kehidupan sehari-hari. Gurol (2011) menyatakan bahwa berpikir reflektif dapat dijadikan sebagai sarana untuk mendorong proses berpikir selama pemecahan masalah. Karena berpikir reflektif memberikan kesempatan untuk belajar dan memikirkan strategi terbaik dalam proses pemecahan masalah tersebut.

Beberapa penelitian yang membahas tentang kemampuan berpikir reflektif (Hidayat, 2018; Nisak, 2013). Hidayat (2018) mendeskripsikan kemampuan berpikir reflektif dalam memecahkan masalah ditinjau dari stress akademik. Nisak (2013) menganalisis kemampuan berpikir reflektif dalam memecahkan masalah berbentuk semantik, figural, dan simbolik.

Artikel ini membahas tentang kemampuan berpikir reflektif siswa dalam menyelesaikan soal HOTS yang ditinjau dari kecerdasan logis matematis siswa. Fokus dalam artikel ini yaitu mendeskripsikan kemampuan berpikir reflektif siswa SMP kelas IX. Siswa yang dipilih sebagai subjek adalah siswa yang memiliki kecerdasan logis matematis tinggi, sedang dan rendah.

Kecerdasan logis-matematis merupakan kecerdasan yang berkaitan erat dengan kemampuan berpikir tingkat tinggi siswa termasuk kemampuan berpikir reflektif. Secara teoritis, kecerdasan logis matematis sebagai salah satu dari kecerdasan majemuk (multiple intellegence). Kecerdasan logis matematis bisa didefinisikan sebagai kapasitas seseorang untuk berpikir secara logis dalam memecahkan kasus atau permasalahan dan melakukan perhitungan matematis (Asis, Arsyad, \& Alimuddin, 2015). 


\section{KAJIAN PUSTAKA}

\section{Kemampuan Berpikir Reflektif}

Tujuan dari pendidikan adalah memberikan kontribusi dalam perkembangan pribadi dan sosial seseorang melalui pengalaman dan pemecahan masalah yang berlangsung secara reflektif. Dewey mengungkapkan definisi berpikir reflektif adalah aktif, terus menerus, gigih, dan mempertimbangkan dengan seksama tentang segala sesuatu alasan yang mendukungnya dan menuju pada suatu kesimpulan (Phan, 2009).

Kemampuan berpikir reflektif adalah kemampuan mengidentifikasi apa yang sudah diketahui, menerapkan pengetahuan yang dimiliki dalam situasi yang lain, memodifikasi pemahaman berdasarkan informasi dan pengalaman-pengalaman baru. Surbeck, Han, dan Moyer mengklasifikasikan kemampuan berpikir reflektif menjadi tiga fase/tingkat yaitu: 1) Reacting : berpikir reflektif untuk aksi, 2) Comparing : berpikir reflektif untuk evaluasi, 3) Contemplating : berpikir reflektif untuk inkuiri kritis (Noer, 2008).

Indikator pada setiap fase atau tingkatan kemampuan berpikir reflektif dimodifikasi dari penelitian yang dilakukan Nisak (2013). Indikator tersebut dapat dilihat pada tabel 1.

TABEL 1. Indikator Kemampuan Berpikir Reflektif

\begin{tabular}{|c|c|c|}
\hline Fase & Indikator & Sumber Asli \\
\hline Reacting & $\begin{array}{ll}\text { a } & \text { Menyebutkan apa yang ditanyakan } \\
\text { b Menyebutkan apa yang diketahui } \\
\text { c Menyebutkan hubungan antara yang } \\
\text { ditanya dengan apa yang diketahui } \\
\text { d Mampu menjelaskan apa yang diketahui } \\
\text { sudah cukup untuk menjawab yang } \\
\text { ditanyakan }\end{array}$ & $\begin{array}{l}\text { Pada tingkat ini siswa } \\
\text { cenderung menggunakan } \\
\text { sumber asli Curiosity } \\
\text { (keingintahuan) }\end{array}$ \\
\hline Comparing & $\begin{array}{l}\text { a. Menjelaskan jawaban pada permasalah } \\
\text { yang pernah didapatkan } \\
\text { b. Mengaitkan masalah yang ditanyakan } \\
\text { dengan masalah yang pernah dihadapi }\end{array}$ & $\begin{array}{l}\text { Pada tingkat ini siswa } \\
\text { cenderung menggunakan } \\
\text { sumber asli Suggestion } \\
\text { (saran) berupa ide yang } \\
\text { dirancang sesuai } \\
\text { pengetahuan yang telah } \\
\text { diketahui. }\end{array}$ \\
\hline $\begin{array}{l}\text { Contempla } \\
\text { ting }\end{array}$ & $\begin{array}{l}\text { a. Menentukan maksud dari permasalahan } \\
\text { b. Mendeteksi kesalahan pada jawaban } \\
\text { c. Memperbaiki dan menjelaskan jika terjadi } \\
\text { kesalahan pada jawaban } \\
\text { d. Membuat kesimpulan dengan benar }\end{array}$ & $\begin{array}{l}\text { Pada tingkat ini siswa } \\
\text { cenderung menggunakan } \\
\text { sumber asli berupa } \\
\text { Orderlinnes (keteraturan) } \\
\text { berdasarkan Curiosity dan } \\
\text { Suggestion. }\end{array}$ \\
\hline
\end{tabular}

Beberapa penelitian yang membahas tentang kemampuan berpikir reflektif (Hidayat, 2018; Nisak, 2013). Penelitian yang dilakukan oleh Hidayat (2018) memperoleh hasil yaitu pada fase reacting, siswa dengan stres akademik rendah, sedang, dan tinggi memenuhi semua indikator. Pada fase comparing, siswa dengan stres akademik rendah dan sedang memenuhi syarat indikator yang harus dilalui. Pada fase contemplating, siswa dengan stres akademik rendah dan sedang memenuhi syarat indikator yang harus dilalui.

Selanjutnya, penelitian yang dilakukan oleh Nisak (2013) memperoleh hasil yaitu kemampuan berpikir reflektif berbanding lurus dengan kemampuan awal matematika siswa. Siswa yang 
kemampuan awal matematikanya tinggi memiliki kemampuan berpikir reflektif yang tinggi dibandingan dengan siswa yang kemampuan awal matematikanya sedang dan rendah.

\section{Kecerdasan Logis Matematis}

Secara teoritis, kecerdasan logis matematis sebagai salah satu dari kecerdasan majemuk (multiple intellegence) bisa didefinisikan sebagai kapasitas seseorang untuk berpikir secara logis dalam memecahkan kasus atau permasalahan dan melakukan perhitungan matematis. Individu dengan kecerdasan logis matematis mempunyai kemampuan mengelola logika dan angka dengan aktivitas utama berpikir logis, berhitung, menyusun pola hubungan serta memecahkan masalah (Asis, dkk., 2015).

Kecerdasan logis matematis merupakan kemampuan seseorang dalam menghitung, mengukur, dan menyelesaikan hal-hal yang bersifat matematis. Berbagai komponen terlibat dalam kemampuan ini. Misalnya berpikir logis, pemecahan masalah, ketajaman dalam melihat pola maupun hubungan dari suatu masalah, pengenalan konsep-konsep yang bersifat kuantitas, waktu dan hubungan sebab akibat (Masykur \& Fathani, 2007).

Artikel yang membahas tentang kecerdasan logis matematis salah satunya adalah artikel yang ditulis oleh Adha dan Rahaju (2020). Mereka menyebutkan bahwa kecerdasan logis-matematis merupakan kecerdasan yang berkaitan erat dengan kemampuan berpikir reflektif. Meskipun berkaitan dengan angka, kecerdasan logis matematis tidak berpusat dalam perhitungan angka secara terus-menerus, melainkan juga mengenai pemecahan masalah matematis. Kecerdasan logis-matematis berhubungan dengan kemampuan ilmiah dan mencakup kemampuan berpikir ilmiah.

\section{METODE PENELITIAN}

Jenis penelitian ini merupakan penelitian kualitatif dengan pendekatan deskriptif. Penelitian ini mendeskripsikan kemampuan berpikir reflektif dalam menyelesaikan soal HOTS ditinjau dari kecerdasan logis matematis siswa. Subjek penelitian ini adalah 3 siswa kelas IX SMP yang mewakili setiap kategori kecerdasan logis matematis (tinggi, sedang, dan rendah). Pengambilan subjek penelitian didasarkan pada hasil tes kecerdasan logis matematis dengan menganalisis skor kecerdasan logis matematis setiap siswa. Pengambilan subjek didasarkan pada tingkat kecerdasan logis matematis berdasarkan nilai yang diperoleh menurut Maryam dan Rosyidi (2016) yaitu:

TABEL 2. Kategori Kecerdasan Logis-matematis

\begin{tabular}{cl}
\hline Nilai & \multicolumn{1}{c}{ Kategori } \\
\hline $80<$ skor yang diperoleh $\leq 100$ & Kecerdasan logis matematis tinggi \\
$60<$ skor yang diperoleh $\leq 80$ & Kecerdasan logis matematis sedang \\
$0<$ skor yang diperoleh $\leq 60$ & Kecerdasan logis matematis rendah \\
\hline
\end{tabular}

Teknik pengumpulan data yang digunakan adalah metode tes dan wawancara. Instrumen dalam penelitian ini meliputi tes kecerdasan logis matematis, tes soal HOTS, dan pedoman wawancara. Tes kecerdasan logis matematis adalah tes yang memuat soal-soal berbentuk pilihan ganda untuk menentukan kategori kecerdasan logis matematis siswa. Tes soal HOTS adalah tes yang berbentuk soal HOTS untuk mengukur kemampuan berpikir reflektif siswa. Dan pedoman wawancara sebagai panduan dalam mengembangkan pertanyaan selama proses wawancara berlangsung sesuai dengan jawaban subjek penelitian. Semua instrumen yang digunakan dalam penelitian ini telah divalidasi oleh validator ahli. 


\section{HASIL DAN PEMBAHASAN}

Pengambilan data pada penelitian ini dilakukan dengan pemberian tes kecerdasan logis matematis, tes soal HOTS, dan wawancara. Pertama, tes kecerdasan logis matematis diberikan pada seluruh siswa kelas IX. Selanjutnya dipilih tiga subjek yang terdiri dari masing-masing kategori kecerdasan logis matematis. Adapun identitas subjek yang dipilih dalam penelitian ini terlihat pada tabel 3 .

TABEL 3. Identitas Subjek Penelitian

\begin{tabular}{lll} 
Kategori & Kode & Nilai \\
\hline Kecerdasan logis matematis tinggi & ST & 84 \\
Kecerdasan logis matematis sedang & SS & 78 \\
Kecerdasan logis matematis rendah & SR & 28
\end{tabular}

Selanjutnya, berdasarkan pemberian tes soal HOTS dan wawancara diperoleh deskripsi kemampuan berpikir reflektif subjek ST, SS, dan SR.

\section{Kemampuan berpikir reflektif siswa dengan kecerdasan logis matematis tinggi}

Dalam menyelesaikan soal HOTS tingkat $\mathrm{C} 4$ atau menganalisis, subjek menyebutkan apa yang ditanyakan, menyebutkan apa yang diketahui, mengetahui hubungan antara yang ditanyakan dan diketahui. Selain itu, subjek juga mengaitkan permasalahan pada saat itu dengan permasalahan yang pernah dihadapi sebelumnya, mengetahui maksud dari permasalahan dan mendeteksi ada tidaknya kesalahan pada jawaban.

\section{TRANSKIP 1}

\begin{tabular}{|c|c|}
\hline P1-07 & "Bagaimana itu caranya?" \\
\hline ST1-07 & $\begin{array}{l}\text { "Kan kak ini soalnya perhatikan sistem persamaan linear berikut yaitu } \\
12 x-2 \text { by }=12 \text { dan } 3 a x-\text { by }=6 \text {. Baru na suruhki tentukan nilai a dan b } \\
\text { sehingga sistem persamaan linear tersebut memiliki selesaian }(2,3) \text {. Jadi kak, } \\
x=2 \text { sama } y=3 \text { " }\end{array}$ \\
\hline P1-08 & "Oke, terus?" \\
\hline ST1-08 & "Terus kak digantimi nilai x menjadi 2 dan y menjadi 3 di soal itu." \\
\hline P1-09 & "Hmm, bagaimana itu?" \\
\hline ST1-09 & $\begin{array}{l}\text { "Lalu kak, yang satunya lagi. } 3 a x-b y=6 \text {. Diganti nilai } x \text { menjadi } 2 \text { dan y } \\
\text { menjadi } 3 \text {, menjadi } 6 a-3 b=6 \text { karena } 3 \times 2=6 \text { dan ini kak } 3 b \text { karena } \\
y=3 \text {, jadi } 3 b \text {. Selanjutnya digantimi lagi nilai b nya menjadi } 2 \text {, didapatmi } \\
6 a-6=6 \text { karena } 3 \times 2=6 \text {. Selanjutnya dipindahkan ke samping itu } 6 \\
\text { menjadi } 6 a=6+6 \text {. Selanjutnya karena } 6+6=12 \text {, menjadi } 6 a= \\
\text { 12. Selanjutnya dipindahkan } 6 \text { menjadi pembagi menjadi } a=\frac{12}{6}, \text { lalu } \\
\text { didapatmi nilai } a=2 . "\end{array}$ \\
\hline$P 1-11$ & "Oke, jadi?" \\
\hline ST1-11 & "Jadi didapatmi kak nilainya $a=2$ dan $b=2 "$ \\
\hline$P 1-12$ & "Oke, pernahki sebelumnya dapat soal yang begini?" \\
\hline$S T 1-12$ & "Iye kak, pernah di sekolah." \\
\hline$P 1-13$ & : "Bagaimana itu soal di sekolah?" \\
\hline ST1-14 & $\begin{array}{l}\text { : "kayak samaji caranya ini kak, cuman di sekolah biasanya nilai } x \text { sama y ny } \\
\text { biasa dicari kak." }\end{array}$ \\
\hline
\end{tabular}


Pada Transkip 1, subjek mengetahui maksud soal dan menyebutkan apa maksud dari informasi yang diketahui (ST1-07). Subjek menjelaskan langkah awal yang dilakukannya dalam menyelesaikan soal yang diberikan (ST1-08). Selanjutnya subjek menjelaskan dengan runtut dan rinci langkah-langkah yang dilakukan untuk mencari nilai a dan b, yaitu dengan menggunakan metode subtitusi (ST1-09). Subjek mengaitkan antara soal dengan permasalahan yang pernah didapatkan, yaitu cara pengerjaannya yang sama (STI-14). Dan subjek menyebutkan kesimpulan yang tepat, yaitu $a=2$ dan $b=2$ (ST1-11).

Subjek dengan kecerdasan logis matematis tinggi dikatakan reflektif dalam menyelesaikan soal HOTS. Subjek dapat melalui fase reacting dengan baik. Subjek mengidentifikasi pertanyaan pada soal dengan jelas dan mengetahui informasi yang digunakan untuk menyelesaikan soal tersebut dengan rinci dan tepat. Subjek dapat melalui fase comparing dengan baik. Subjek dengan mudah mengingat materi pelajaran yang berkaitan dengan soal yang diberikan dan langsung menghubungkannya dengan soal serupa yang pernah diperolehnya. Selanjutnya, subjek melalui fase contemplating. Subjek menyelesaikan soal yang diberikan mengacu pada pengetahuan yang diingatnya dengan baik.

\section{Kemampuan berpikir reflektif siswa dengan kecerdasan logis matematis sedang}

Dalam menyelesaikan soal HOTS tingkat $\mathrm{C} 4$ atau menganalisis, subjek menyebutkan apa yang ditanyakan, menyebutkan apa yang diketahui, mengetahui hubungan antara yang ditanyakan dan diketahui, mengaitkan permasalahan pada saat itu dengan permasalahan yang pernah dihadapi sebelumnya, mengetahui maksud dari permasalahan dan mendeteksi ada tidaknya kesalahan pada jawaban.

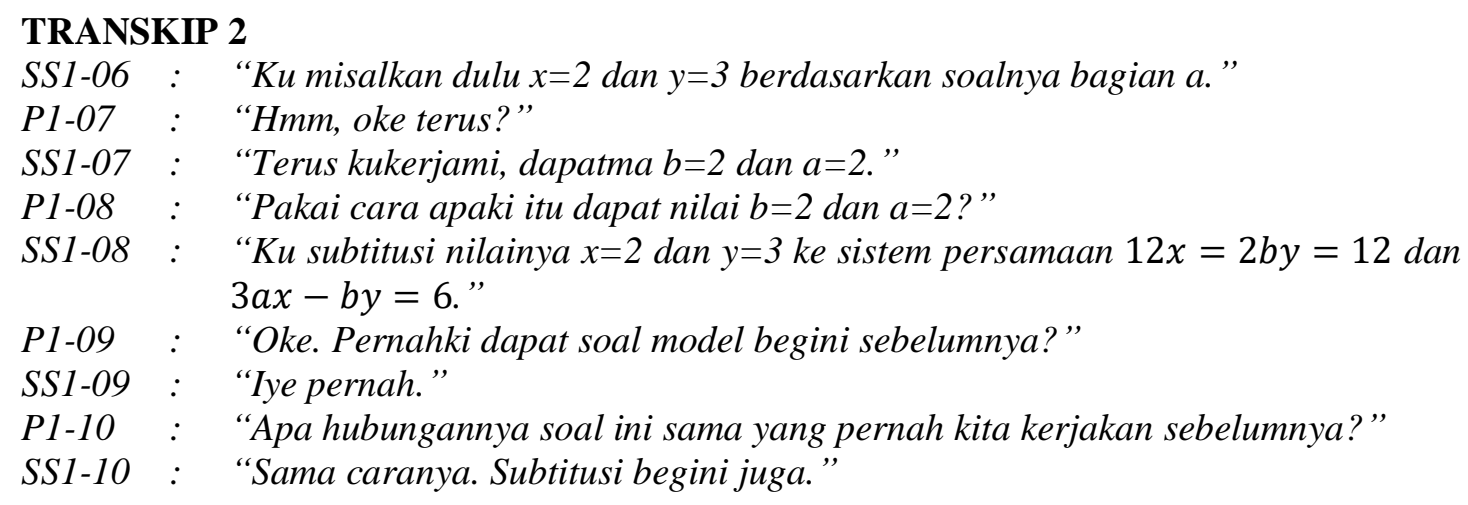

Pada Transkip 2, subjek menyebutkan langkah awal yang dilakukan untuk mengerjakan soal (SS1-06). Selanjutnya, subjek menjelaskan langkah-langkah penyelesaian yang digunakan dalam menyelesaikan soal yang diberikan, yaitu menggunakan metode subtitusi (SS1-08). Subjek juga mengenali soal serupa yang pernah dihadapi sebelumnya (SS1-09). Kemudian subjek mengaitkan antara soal dengan permasalahan yang pernah didapatkan, yaitu cara pengerjaannya yang sama (SSI-10).

Subjek dengan kecerdasan logis matematis sedang dikatakan cukup reflektif dalam menyelesaikan soal HOTS. Subjek dapat melalui fase reacting dengan baik. Subjek mengidentifikasi pertanyaan pada soal dengan jelas dan mengetahui informasi yang digunakan untuk menyelesaikan soal tersebut dengan rinci dan tepat. Subjek dapat melalui fase comparing dengan baik. Subjek dapat mengingat materi pelajaran yang berkaitan dengan soal yang diberikan. Dan subjek juga mengaitkan antara soal yang diberikan dengan soal serupa yang pernah dihadapi sebelumnya. Subjek melalui fase contemplating pada soal nomor C4. Subjek menyelesaikan soal yang diberikan mengacu pada pengetahuan yang diingatnya. 


\title{
Kemampuan berpikir reflektif siswa dengan kecerdasan logis matematis rendah
}

Dalam menyelesaikan soal HOTS tingkat C5 atau mengevaluasi, subjek menyebutkan apa yang ditanyakan, menyebutkan apa yang diketahui, mengetahui hubungan antara yang ditanyakan dan diketahui, namun belum mampu mengaitkan permasalahan pada saat itu dengan permasalahan yang pernah dihadapi sebelumnya.

\section{TRANSKIP 3}

\author{
P1-27 : "Terus kita tau apa hubungannya ini diketahui sama ditanyakan?" \\ SR1-27 : "Yang ini kak ditanyakan mau dicari pakai ini diketahui." \\ P1-28 : "Coba sebutki apa yang mau dicari di bagian a ini?" \\ SR1-28 : "Berapakah waktu yang dibutuhkan jika pekerjaan tersebut dikerjakan oleh 15 \\ pria dan 20 perempuan?" \\ P1-29 : "Diketahuinya apa?" \\ SR1-29 : "Sebuah pekerjaan dapat diselesaikan dalam waktu 10 hari oleh 6 pria dan 8 \\ perempuan. Namun, jika pekerjaan tersebut dikerjakan oleh 26 pria dan 48 \\ perempuan, maka waktu yang dibutuhkan untuk menyelesaikannya hanya 2 \\ hari."
}

Pada Transkip 3, subjek mengetahui hubungan antara yang ditanyakan dan diketahui (SR1-27). Namun ketika ditanya mengenai apa yang ditanyakan, subjek hanya menyebutkan apa yang tertera pada lembar soal tanpa memberikan penjelasan yang mengarahkan untuk menjawab soal (SR1-27). Begitupun ketika menyebutkan informasi yang diketahui, subjek hanya sekedar membaca soal yang diberikan (SR1-29).

Subjek dengan kecerdasan logis matematis rendah dikatakan kurang reflektif dalam menyelesaikan soal HOTS. Subjek dapat memenuhi syarat indikator untuk melalui fase reacting setelah diberikan beberapa pertanyaan terkait soal. Subjek dapat mengidentifikasi pertanyaan pada soal dan mengetahui informasi yang digunakan untuk menyelesaikan soal tersebut melalui wawancara. Selanjutnya subjek tidak melalui fase comparing dan fase contemplating untuk setiap nomor. Subjek tidak dapat mengingat dengan baik materi pelajaran yang berkaitan dengan soal yang diberikan. Dan subjek terlihat tidak berusaha untuk menggali ingatannya terkait soal serupa yang pernah dihadapi. Subjek masih kesulitan dalam memahami maksud soal dengan jelas, dan subjek hanya menyimpulkan jawaban tanpa melakukan langkah-langkah penyelesain yang jelas. Kesimpulan yang diberikan pun tidak tepat.

\section{KESIMPULAN}

Subjek dengan kecerdasan logis matematis tinggi dapat melalui fase reacting, comparing, dan contemplating dalam berpikir reflektif. Subjek bereaksi dengan pemahaman pribadinya dalam mengidentifikasi pertanyaan pada soal dan menentukan informasi yang digunakan untuk menyelesaikan soal tersebut dengan rinci dan tepat. Kemudian, subjek melakukan analasis dan evaluasi terhadap pengetahuannya dan menghubungkan soal yang diberikan dengan soal serupa yang pernah diperolehnya. Dalam menyelesaikan soal yang diberikan, subjek mengacu pada pengetahuan yang diingatnya, lalu membuat kesimpulan jawaban yang tepat.

Subjek dengan kecerdasan logis matematis sedang dapat melalui fase reacting dan comparing dalam berpikir reflektif. Subjek bereaksi dengan pemahaman pribadinya dalam mengidentifikasi pertanyaan pada soal dan menentukan informasi yang digunakan untuk menyelesaikan soal tersebut dengan tepat. Kemudian, subjek melakukan analasis dan evaluasi terhadap pengetahuannya dan menghubungkan soal yang diberikan dengan soal serupa yang pernah diperolehnya. Namun, subjek tidak melalui fase contemplating dalam berpikir reflektif. Subjek 
berusaha untuk menyelesaikan soal yang diberikan, meskipun subjek sendiri tidak memahami maksud soal dengan tepat dan juga tidak yakin dengan langkah penyelesaian yang digunakan.

Subjek dengan kecerdasan logis matematis rendah dapat memenuhi syarat indikator untuk melalui fase reacting dalam berpikir reflektif. Subjek bereaksi dengan pemahaman pribadinya dalam mengidentifikasi pertanyaan pada soal dan menentukan informasi yang digunakan untuk menyelesaikan soal tersebut. Namun subjek tidak melalui fase comparing dan contemplating dalam berpikir reflektif. Subjek tidak mengingat materi pelajaran yang berkaitan dengan soal yang diberikan. Dan subjek terlihat tidak berusaha untuk menggali ingatannya terkait soal serupa yang pernah dihadapi. Kemudian, subjek kesulitan dalam merekontruksi pengetahuan pribadinya dalam memahami maksud soal, dan subjek hanya menyimpulkan jawaban tanpa melakukan langkah-langkah penyelesain yang jelas.

\section{DAFTAR PUSTAKA}

Adha, S. M., Rahaju, E. B. (2020). Profil Berpikir Reflektif Siswa SMA dalam Memecahkan Masalah Matematika ditinjau dari Kecerdasan Logis Matematis. Jurnal Penelitian Matematika dan Sains, 4. 61-71.

Asis, M., Arsyad, N., Alimuddin. (2015). Profil Kemampuan Spasial dalam Menyelesaikan Masalah Geometri Siswa yang Memiliki Kecerdasan Logis Matematis Tinggi Ditinjau dari Perbedaan Gender. Jurnal Daya Matematis, 3. 78-87.

Fisher, A. (2001). Critical Thinking: An Introduction. Cambridge: Cambridge University Press.

Gunawan, A. W. (2011). Born to be a Genius. Jakarta: Gramedia Pustaka Utama.

Gurol. A. (2011). Determining the reflective thinking skills of pre-service teachers in learning teaching process. Energy Education Science and Technology Part B: Social and Educational Studies, 3. 387-402.

Hidayat, A. (2018). Deskripsi Kemampuan Berpikir Reflektif dalam Memecahkan Masalah Matematika pada Siswa Kelas IX SMP 1 Makassar Ditinjau dari Stres Akademik (Skripsi, tidak dipublikasi). Universitas Negeri Makassar, Makassar.

Kemendikbud. (2017). Modul Penyusunan Higher Order Thinking Skill (HOTS). Jakarta: Direktorat Jenderal Pendidikan Dasar dan Menengah Departeman Pendidikan dan Kebudayaan.

Maryam, S., Rosyidi, A. H. (2016). Representasi Siswa SMP dalam Menyelesaikan Soal OpenEnded ditinjau dari Kemampuan Matematika. Jurnal Ilmiah Pendidikan Matematika, 1. 74-79.

Masykur, M., Fathani, A. H. (2007). Mathematical Intelligence: Cara Cerdas Melatih Otak dan Menanggulagi Kesulitan Belajar. Yogykarta: Ar-Ruzz Media.

Nisak, L. (2013). Analisis Kemampuan Berpikir Reflektif Siswa dalam Memecahkan Masalah Berbentuk Semantik, Figural, dan Simbolik pada Pokok Bahasan Fungsi Kelas XI IPA di MAN Nglawak Kertosono Nganjuk (Skripsi, tidak dipubliskan). Institut Agama Islam Sunan Ampel, Surabaya.

Noer, S. H. (2008). Problem-Based Learning dan Kemampuan Berpikir Reflektif dalam Pembelajaran Matematika. Semnas Matematika dan Pendidikan Matematika (hal. 267280). Yogyakarta, Indonesia: Universitas Negeri Yogyakarta.

Phan, P. H. (2009). Reflective thinking, effort, persistence, disorganization, and academic performance: A mediational approach. Electronic Journal of Research in Educational Psychology, 7. 927-952. 
Widodo, T., Kadarwati, S. (2103). Higher Order Thinking Berbasis Pemecahan Masalah Untuk Meningkatkan Hasil Belajar Berorientasi Pembentukan Karakter Siswa. Cakrawala Pendidikan, XXXII. 161-171. 